\title{
Ocular Complications of Intravitreal Avastin: a Report from Tobruk Medical Center
}

\author{
Fathy A. Abdolmejed ${ }^{1 *}$ and Ghamela S. Ali ${ }^{2}$ \\ ${ }^{1}$ Ophthalmology Department, Tobruk University, Tobruk, Libya \\ ${ }^{2}$ Pediatric Department, Tobruk University, Tobruk, Libya.
}

Received: 03 February 2020/ Accepted: 20 July 2020

Doi: https://doi.org/10.54172/mjsc.v35i2.317

\begin{abstract}
A retrospective statistical study was done at the ophthalmology department of Tobruk Medical Center on all the patients who received intravitreal medication with Avastin (anti-VEGF (anti-vascular endothelial growth factor)) in the period between August $1^{\text {st }}$ and December $31^{\text {st }}$, 2018. It is aimed to report the complications of the intravitreal injection (IVI) and how they were managed. Out of the 56 recorded patients, there were 32 (51.9\%) females, all the patients received multiple intravitreal injections, with a total number of 131 injections. The average age of the patients was 56.5 years (ranged from $40-70$ years). The most common complications after intravitreal injection were subconjunctival hemorrhage (19\%), discomfort/pain (13.7\%), blurring of vision (6 $\%$ ), leaking at injection site $(4.6 \%)$, floaters $(3 \%)$, and increase intraocular pressure (IOP) in (13.7\%). Six cases out of the eighteen that had high IOP received Diamox (Acetazolamide) Tab. $250 \mathrm{mg}$ one-two hours before the time of injection which did not prevent the post-injection spike of IOP and that was statistically not significant $(P=0.09)$. Thirteen eyes $(10 \%)$ developed sudden loss of vision due to sudden increase in IOP immediately after the injection, and all the cases of the high IOP were managed by anterior chamber paracentesis and the vision also improved. Endophthalmitis was recorded in only one case $(0.8 \%)$, at the third-day post intraocular Avastin injection, the causative microorganism was unknown and treated with intravitreal antibiotics (vancomycin) along with topical and systemic antibiotics and steroids, but the patient did not recover until pars plana vitrectomy was done to him, and the patient recovered his preoperative vision. The patients who had glaucoma or rubeosis iridis suffered significantly $(\mathrm{P}=0.01)$ from an increase in IOP levels (digitally measured) after injection with Avastin, while most other patients who didn't have both pathologies did not suffer from an increase in IOP. Concluded that despite Anti-VEGF has a dramatic effect on the quality of life by improving the central vision, it can cause serious complications that could be prevented by early diagnosis and treatment.
\end{abstract}

Keywords: Avastin; Complications; Intravitreal Injection; Tobruk.

\section{INTRODUCTION}

Sub-retinal neovascularization and pathologic ocular angiogenesis are common causes of progressive, irreversible impairment of central vision, and dramatically affect the quality of life. Anti-vascular endothelial growth factor (anti-VEGF) therapy has improved the quality of life for many patients with agerelated macular degeneration, diabetic reti- nopathy, and other ocular diseases involving neovascularization and edema. In these pathologies, the inhibition of intraocular VEGF is the only therapy that can preserve vision. (Semeraro et al., 2015).

Adverse events following intravitreal antiVEGF injections have no relation to underlying ocular disease; Common complications of intravitreal injection (IVI) are injection site 
discomfort, subconjunctival hemorrhage, vitreous reflux, transient intraocular pressure (IOP) elevation, and defective vision. The patient may also develop floaters, vitreous or retinal hemorrhage, and retinal detachment. (Frenkel et al., 2010). The most dreaded complications of intravitreal injection are endophthalmitis and loss of vision. (Aiello et al., 2004).

The intravitreal injection can cause an immediate rise in intraocular pressure IOP (spike) that is not merely the result of added volume, but also for the properties of the injected drug. The sudden increased intraocular pressure (IOP), due to various reasons, causes corneal edema and damage to the endothelial cells with optic nerve damage and can lead to significant loss of vision. (Fang et al., 2006). Intraocular pressure spikes after intravitreal injections of Anti-VEGF are common, and in most cases transient, and usually return to baseline in a few minutes. (Qureshi et al., 2016) The increase of the IOP may take longer to normalize in patients with glaucoma and need to be monitored. In patients who develop high IOP spikes, the use of ocular massage, topical IOP reducing agent, oral medication, and anterior chamber tap can be used as means to reduce IOP to prevent optic nerve damage and possibility central retinal artery occlusion. (Uyar, et al., 2019). In patients who have primary open-angle glaucoma or ocular hypertension, the intravitreal injection is not considered a contraindication. It requires closer observation and the use of topical medical therapy. (Frenkel et al., 2010; Aiello et al., 2004).

Post intravitreal injections endophthalmitis is a serious inflammation within the eye due to bacterial or fungal infection, including involvement of the vitreous and/or aqueous humor. It usually causes irreversible damage to retinal photoreceptors that may lead to loss of vision, even with intensive medical and surgical management. The post intraocular injection's endophthalmitis is rare. It accounts for $0.03 \%-0.072 \%$ of all cases of antivascular endothelial growth factor (VEGF) injection (Hoevenaars, et al., 2012; Park, et al., 2014). The most common causative organisms are Coagulase-negativestaphylococci, Staphylococcus aureus, and Streptococci viridians. The post anti-VEGF injection endophthalmitis, in general, has a moderate visual outcome of 6/60 if managed properly in comparison with other types of endophthalmitis (Dhoot, et al., 2013; Solborg et al., 2013).

Although matters have improved recently with fast diagnosis and better management of endophthalmitis, this disease is still serious and can lead to destructive complications to the eye that may be irreversible, and sometimes cause blindness. (Barry, et al., 2013). In most cases of post intravitreal endophthalmitis, the bacterial endotoxins and other bacterial products appear to cause a direct cellular inflammatory effect. The inflammation is most often in the first 3-4 days after the operation. (Solborg, et al., 2013). The most commonly reported causes of endophthalmitis after surgery are from the patient's conjunctival flora, contamination of sterilized instruments, disposable supplies, prepared solutions, surgical field, or the intraocular lens. (Dancer, et al., 2012; Damasceno et al., 2015).

Aim of the study: This article is intended to highlight important aspects of post-injection complications and how to deal with these complications to avoid the risk of a serious outcome, which may lead to permanent vision loss.

\section{MATERIALS AND METHODS}

A retrospective study was done through data collection from the Statistical office in Tobruk Medical Center. Statistical analysis was performed using Microsoft Office Excel program. $P$-value $\leq 0.05$ or a level of $(95 \%)$ was consid- 
ered statistically significant. Unfortunately, the International Classification of Disease (ICD) codes are not used in Tobruk Medical Center. Data were collected from the files of 56 admitted patients (131 eyes) in the period between August $1^{\text {st }}$ and December $31^{\text {st }}, 2018$; there were 24 male cases (received 63 injections) and 32 female cases (received 68 injections). The recorded data included patient diagnosis, time of the injection, place of operation, clinical features, complications soon after the time of injection, and later at the first post-operative day, and method of management of these complications. All the cases received an intravitreal injection of $2.5 \mathrm{mg} / 0.1 \mathrm{ml}$ of Avastin with a 27 Gauge needle, cleaning of periocular skin with $10 \%$ povidone-iodine solution, after 60 seconds the eyelids were retracted with a speculum to avoid contamination by lashes, and topical povidone-iodine $5 \%$ was instilled into the conjunctival sac $2 \mathrm{~min}$ before the injection. All the IVIs were done by the same surgeon in the OT room in complete aseptic conditions. The site of injection was in the upper temporal area. Routine prophylactic use of IOP-lowering medications with Diamox (Acetazolamide) Tab. $250 \mathrm{mg}$ one-two hours before the time of injection was given to 52 patients. The ocular digital massage measurement of IOP was done after the anti-VEGF injection in all eyes. The fundus was observed by a direct ophthalmoscope to control the central retinal artery (CRA) perfusion. All the patients underwent anterior-chamber paracentesis and Fundus examination after the IVIs injections were administered by the same treating ophthalmologist.

\section{RESULTS}

There were 56 patients with an average age of 56.5 years and ranged from (40-70 years). They received 131 injections, 68 (51.9\%) of which were females. The indications for the Avastin injections were; exudative age-related macular degeneration (AMD), diabetic macular edema (DME), branch retinal vein occlusion (BRVO), and ocular ischemia (OI) which oc- curs most of the time in patients with old age (table 1).

Table:(1). The indications for the Avastin injections in the study group

\begin{tabular}{llc}
\hline \hline Diagnosis & Avastin indication & $\begin{array}{c}\text { No. of total injected } \\
\text { eyes (injections) }\end{array}$ \\
\hline DME & Cystoid macular edema & 125 \\
BRVO & Cystoid macular edema & 3 \\
& \\
AMD & $\begin{array}{l}\text { Wet age-related macu- } \\
\text { lar degeneration }\end{array}$ \\
& \\
OI & Rubeosis iridis & 1 \\
\hline \hline $\begin{array}{l}\text { DME; diabetic macular edema, BRVO; Branch retinal vein } \\
\text { occlusion, AMD; Age related maculopathy, OI; Ocular ische- } \\
\text { mia }\end{array}$
\end{tabular}

In the present study, most of the cases with DME had cystoid macular edema (95.4\%). Some of these patients were having other ocular pathologies as shown in table 2 .

Table:(2). Patients with other ocular pathologies associated with DME

\begin{tabular}{cccc}
\hline \hline Total & $\begin{array}{c}\text { DME ass. } \\
\text { with rube- } \\
\text { cases } \\
\text { osis iridis }\end{array}$ & $\begin{array}{c}\text { DME ass. } \\
\text { With COAG }\end{array}$ & $\begin{array}{c}\text { DME ass. With } \\
\text { retinal neovascu- } \\
\text { larization }\end{array}$ \\
\hline 125 & 9 & 5 & 7 \\
\hline \hline
\end{tabular}

DME; Diabetic macular edema, COAG; Chronic open angle glaucoma.

About 93 eyes (71\%) developed complications because of the intravitreal injection. There were some transient and easily treatable complications that did not lead to dangerous or permanent insult to the eyes like subconjunctival hemorrhage, eye pain/ discomfort, floaters, and blurred vision. Other rare but serious complications such as endophthalmitis, vitreous hemorrhage, and transient loss of vision due to an acute increase in IOP at the time of injection were also recorded. Serious 
complications, like retinal detachment and central artery occlusion, were not recorded in this study. (table 3).

Table:(3). Complications after intra ocular Avastin injection in the study group (93 out of 131 eyes (injection))

\begin{tabular}{|c|c|c|c|}
\hline Complication & $\begin{array}{l}\text { Time in days } \\
\text { of complica- } \\
\text { tions } \\
\text { after the in- } \\
\text { jections }\end{array}$ & $\begin{array}{l}\text { Number of } \\
\text { eyes (\%) } \\
\text { with compli- } \\
\text { cations }\end{array}$ & $\begin{array}{l}\text { Gen- } \\
\text { der }\end{array}$ \\
\hline $\begin{array}{l}\text { Subconjuncti- } \\
\text { val hemor- } \\
\text { rhage. }\end{array}$ & $\begin{array}{l}\text { Soon after } \\
\text { injection }\end{array}$ & $\begin{array}{l}25 \mathrm{pts} . \\
(19 \%)\end{array}$ & $\begin{array}{l}15 \mathrm{~F} \\
10 \mathrm{M}\end{array}$ \\
\hline $\begin{array}{l}\text { Discomfort/ } \\
\text { pain }\end{array}$ & $\begin{array}{l}\text { First post } \\
\text { injection day }\end{array}$ & $\begin{array}{l}18 \text { pts. } \\
(13.7 \%)\end{array}$ & $\begin{array}{l}10 \mathrm{~F} \\
8 \mathrm{M}\end{array}$ \\
\hline Blurred vision & $\begin{array}{l}\text { First post } \\
\text { injection day }\end{array}$ & $\begin{array}{l}8 \text { pts. } \\
(6 \%)\end{array}$ & $\begin{array}{ll}4 \mathrm{~F} \\
4 \mathrm{M}\end{array}$ \\
\hline Floaters & $\begin{array}{l}\text { First post } \\
\text { injection day }\end{array}$ & $\begin{array}{l}4 \text { pts. } \\
(3 \%)\end{array}$ & $\begin{array}{l}3 \mathrm{~F} \\
1 \mathrm{M}\end{array}$ \\
\hline Increase IOP & $\begin{array}{l}\text { Day of injec- } \\
\text { tion }\end{array}$ & $\begin{array}{l}18 \text { pts. } \\
(13.7 \%)\end{array}$ & $\begin{array}{l}11 \mathrm{~F} \\
7 \mathrm{M}\end{array}$ \\
\hline $\begin{array}{l}\text { Sudden loss of } \\
\text { vision }\end{array}$ & $\begin{array}{l}\text { Soon after } \\
\text { injection }\end{array}$ & $\begin{array}{l}\text { 13pts. } \\
(10 \%)\end{array}$ & $\begin{array}{ll}7 & \mathrm{~F} \\
6 & \mathrm{M}\end{array}$ \\
\hline $\begin{array}{l}\text { Leak at site of } \\
\text { injection }\end{array}$ & $\begin{array}{l}\text { Soon after } \\
\text { injection }\end{array}$ & $\begin{array}{l}6 \text { pts. } \\
(4.6 \%)\end{array}$ & $\begin{array}{l}5 \mathrm{~F} \\
1 \mathrm{M}\end{array}$ \\
\hline $\begin{array}{l}\text { Endophthalmi- } \\
\text { tis }\end{array}$ & $\begin{array}{l}\text { Third day } \\
\text { post the in- } \\
\text { jection }\end{array}$ & $\begin{array}{l}1 \text { pts. } \\
(0.8 \%)\end{array}$ & $1 \mathrm{M}$ \\
\hline
\end{tabular}

IOP; Intraocular pressure.

There was no statistical significance for the post-Avastin injection complications among gender $(P=0.46)$.

There were eighteen eyes (13.7\%) complicated with increase IOP post-Avastin injection (11 females and 7 males), out of them; Six had received Diamox (Acetazolamide) Tablet $250 \mathrm{mg}$ one-two hours before the time of injection.

Cases with glaucoma or rubeosis iridis had no statistically significant difference from those free from it $(P=0.09)$. In both groups, the rise of IOP was relieved with anterior chamber tap.

Thirteen eyes (10\%) developed a sudden increase in the IOP on the operating table imme- diately after the injection (digitally measured IOP showed hard resistance along with corneal edema and decrease vision), which resolved by anterior chamber tap. On the first postoperative day, all of them regained the baseline vision they had before the injection.

The patients who had glaucoma or rubeosis iridis suffered significantly $(P=0.01)$ from increase IOP (digitally measured) after injection with Avastin, while most other patients who didn't have both pathologies didn't suffer from an increase in IOP.

Endophthalmitis was recorded only in one eye $(0.8 \%)$ on the third day after the injection. The diagnosis of endophthalmitis was made clinically (patient had severe pain, redness, decreased vision associated with hypopyon, and vitreous opacities detected by ultrasonography). The patient was treated with intravitreal antibiotics (vancomycin) along with topical and systemic antibiotics and steroids, but he did not recover until pars plana vitrectomy was done to him.

\section{DISCUSSION}

The Needle Gauge for the intravitreal medication injection is not only important for patient comfort, but also for a safe injection procedure and efficient outcome. The most commonly used needle size ranges from 27 to 30 gauge. Pulido et al., (2007) confirmed that smaller scleral holes and less structural damage occur with decrease needles gauge, independently on the injection technique used, such as the tunneled or the perpendicular technique. Oztas, et al., (2016) reported the location of intravitreal medication should be made through the pars plana, between 3.5 and $4 \mathrm{~mm}$ from the limbus; posterior to $4 \mathrm{~mm}$ can lead to an increased risk of retinal detachment, while a more anterior location increases the risk of traumatic cataract formation. They also recommended avoiding injection in per sclerotomy areas, to prevent vitreous incarceration and a persisting scleral hole. 
Tufan, et al., (2013) confirm the intravitreal injection can be safely performed in 360 degrees through the pars plana. Patients who receive an injection of Avastin may experience less severe side effects related to the preparation procedure. These side effects may include eye pain, subconjunctival hemorrhage, vitreous floaters, inflammation of the eye, and visual disturbances. Other possible complications and side effects of the procedure and administration of Avastin, but not recorded in this study, include but are not limited to retinal detachment, cataract formation, hypotony, permanent damage to the retina or cornea, and bleeding (Hoguet, et al., 2019). The volume change of the vitreous cavity may be the main reason for immediate IOP increasing after Anti-VEGF intravitreal injections. The volume of the vitreous cavity in the human eye is approximately $4 \mathrm{ml}$, and the volume of Avastin injected into the vitreous is $0.1 \mathrm{ml}$. Therefore, the increase in fluid volume of the vitreous cavity is $2.5 \%$ approximately, which may cause immediate IOP elevation (Song et al., 2016). Transient vision loss is a poorly understood complication of intravitreal injections, (Fang et al., 2006; Uyar, et al., 2019) reported the increased intraocular pressure (IOP) causes corneal edema and damage to the endothelial cells with optic nerve damage and can lead to significant loss of vision. Longterm deformation can cause a significant effect on the endothelial function and it may result in endothelial dysfunction. (Fang et al., 2006) suggested high IOP may affect the function of the endothelial pump and induced corneal edema. It also reduces intraocular blood flow, induces hypoxia and oxidative stress and as a result, could damage the optic nerve. Transient IOP spikes mostly leave the healthy eye without permanent damage to the vascular optic nerve. (Callegan et al., 2002) confirm the IOP has to be rigorously controlled in patients vulnerable to vascular optic nerve damage, which are patients with glaucoma as well as patients predisposed to anterior ischemic optic neuropathy or retinal vein occlusion. It has been reported that $13.7 \%$ of patients receiving intravitreal
Avastin experienced an IOP rise (digitally hard) after the injection. Hollands et al., (2007) and Song et al. (2016) confirm the patients with a history of glaucoma sustained a rise of IOP with the loss of vision significantly high, suggesting that glaucomatous eyes (higher risk eyes) should be identified before anti-VEGF injections and monitored carefully postinjection for IOP spikes that can cause visual field deterioration. In this study, the 13 cases $(10 \%)$ which had a sudden loss of vision were all managed with paracentesis to reduce the high IOP. The vision was improved significantly with no permanent vascular or optic nerve damage. Bertino (2009) showed that a combination of topical anti-glaucoma therapy and performing ocular decompression massages before the procedure significantly reduce IOP. Frenkel, et al., (2011) had reported that prophylactic medication did not prevent postinjection IOP spikes. In the present study; the use of prophylaxis systemic Diamox Tablets to reduce intraocular pressure was statistically not significant $(P=0.09)$. Patients with and without glaucoma showed a similar rate of IOP normalization.

While the development of targeted molecular therapy to inhibit vascular endothelial growth factor (VEGF) has revolutionized the treatment and visual prognosis of highly prevalent retinal diseases such as diabetic retinopathy and agerelated macular degeneration, each intravitreal injection of these agents carries a risk of endophthalmitis which can be visually devastating (Sachdeva et al, 2016). The post-IVI injection endophthalmitis is rare, accounting for $0.03 \%-0.072 \%$ of all cases of anti-endothelial vascular growth factor (VEGF) injections (Hoevenaars, et al, 2012; Park, et al, 2014). In most cases of post-intravitreal medication, the endophthalmitis is acute, occurring mostly in $<28$ days after the injection (Hoveenaars et al., 2012 and Shah et al., 2011), it should be suspected in cases of persistent vitritis following treatment, and these cases may require vitrectomy to remove the infected vitreous (Sachdeva, et al, 2016). Similarly, in the present study, 
this serious post-operative endophthalmitis was recorded in one case $(0.8 \%)$, it occurred in the first 3 days after the injection, not responding to intravitreal antibiotics and improved by vitrectomy. There are several limitations to the present study. First, the most important limitation is that the IOP was measured digitally because of the unavailability of a non-contact tonometer, and fear that a contact tonometer may increase the risk of infection. Second, the central corneal thickness was not measured in this study, and the effect would be investigated in an advanced study. In addition, this study only focused on the short-term effect of the acute rise in IOP, so we recommend investigating the long term effects in future studies.

\section{CONCLUSION}

Despite Anti-VEGF having a dramatic effect on the quality of life by improving the central vision in ocular angiogenic disease processes, it can cause different complications, which could be transient like intraocular pressure spikes, or serious like endophthalmitis, that could be prevented by early diagnosis. Apart from glaucoma patients, routine prophylactic use of IOPlowering medications is essentially ineffective in preventing IOP spikes after intravitreal injection, and routine monitoring of IOP in glaucoma patients receiving intravitreal anti-VEGF therapy is recommended. Also, post-antiVEGF injection complications are not related to gender.

\section{ACKNOWLEDGEMENT}

We would like to thank Mr. Hafez E.L Mansour (Lecturer at Tobruk University) for his help with data retrieval and statistical analysis, and the Ophthalmology staff at Tobruk Medical Center for their great assistance in collecting the data.

\section{REFERENCES}

Aiello, L. P., Brucker, A. J., Chang, S., Cunningham, E. T., Jr, D'Amico, D. J.,
Flynn, H. W., Jr, Grillone, L. R., Hutcherson, S., Liebmann, J. M., O'Brien, T. P., Scott, I. U., Spaide, R. F., Ta, C., \& Trese, M. T. (2004). Evolving guidelines for intravitreous injections. Retina (Philadelphia, Pa.), 24(5 Suppl), S3-S19. https://doi.org/10.1097/00006982200410001-00002

Barry P, Cordovés L, Gardner S.(2013). ESCRS Guidelines for Prevention and Treatment of Endophthalmitis following Cataract Surgery: Data, Dilemmas and Conclusions. Paper Presented at the European Society of Cataract and Refractive Surgeons. Dublin, Ireland:

2013.https://www.escrs.org/downloads/ Endophthalmitis-Guidelines.pdf. Accessed July 25, 2020

Bertino J. S., Jr (2009). Impact of antibiotic resistance in the management of ocular infections: the role of current and future antibiotics. Clinical ophthalmology (Auckland, N.Z.), 3, 507-521. https://doi.org/10.2147/opth.s5778

Callegan, M. C., Engelbert, M., Parke, D. W., 2nd, Jett, B. D., \& Gilmore, M. S. (2002). Bacterial endophthalmitis: epidemiology, therapeutics, and bacteriumhost interactions. Clinical microbiology reviews, 15(1), 111-124. https://doi.org/10.1128/cmr.15.1.111124.2002

Damasceno, N. P., Horowitz, S. A., \& Damasceno, E. F. (2016). Leuconostoc as a Cause of Endophthalmitis Postintravitreal Injection of Ranibizumab. Ocular immunology and inflammation, 24(1), 118-119. https://doi.org/10.3109/09273948.2014. 898073. 
Dancer, S. J., Stewart, M., Coulombe, C., Gregori, A., \& Virdi, M. (2012). Surgical site infections linked to contaminated surgical instruments. The Journal of hospital infection, 81(4), 231-238. https://doi.org/10.1016/j.jhin.

2012.04.023

Dhoot SB, Kunjukunju N, Sabates N. (2013).The role of prophylactic antibiotic use in prevention of endophthalmitis following intravitreal injection of anti-vascular endothelial growth factor agents: a meta-analysis. Open $J$ Ophthalmol., 3(2):46-49.

Fang, Y. T., Chien, L. N., Ng, Y. Y., Chu, H. F., Chen, W. M., Cheng, C. Y., \& Wu, S. C. (2006). Association of hospital and surgeon operation volume with the incidence of postoperative endophthalmitis: Taiwan experience. Eye (London, England) , 20(8), 900-907. https://doi.org/-10.1038/sj. eye.6702045

Frenkel, M.P., Haji, S.A. and Frenkel, R.E. (2010) Effect of Prophylactic Intraocular Pressure-Lowering Medication on Intraocular Pressure Spikes after Intravitreal Injections. Arch Ophthalmol, 128, 1523-1527.

http://dx.doi.org/10.1001/archophthalm ol.2010.297

Hoevenaars, N. E., Gans, D., Missotten, T., van Rooij, J., Lesaffre, E., \& van Meurs, J. C. (2012). Suspected bacterial endophthalmitis following intravitreal antiVEGF injection: case series and literature review. Ophthalmologica. Journal international d'ophtalmologie. International journal of ophthalmology. Zeitschrift fur Augenheilkunde, 228(3), 143-147.

https://doi.org/10.1159/000339584

Hoguet, A., Chen, P. P., Junk, A. K., Mruthyunjaya, P., Nouri-Mahdavi, K.,
Radhakrishnan, S., Takusagawa, H. L., \& Chen, T. C. (2019). The Effect of Anti-Vascular Endothelial Growth Factor Agents on Intraocular Pressure and Glaucoma: A Report by the American Academy of Ophthalmology. Ophthalmology, 126(4), 611-622.

Hollands, H., Wong, J., Bruen, R., Campbell, R. J., Sharma, S., \& Gale, J. (2007). Short-term intraocular pressure changes after intravitreal injection of bevacizumab. Canadian journal of ophthalmology. Journal canadien d'ophtalmologie, 42(6), 807-811. https://doi.org/10.3129/i07-172

Oztas, Z., Akkin, C., Afrashi, F., \& Nalcaci, S. (2016). The short-needle intravitreal injection technique. International journal of ophthalmology, 9(6), 929-930. https://doi.org/10.18240/ijo.2016.06.24

Park, J. C., Ramasamy, B., Shaw, S., Prasad, S., \& Ling, R. H. (2014). A prospective and nationwide study investigating endophthalmitis following pars plana vitrectomy: incidence and risk factors. The British journal of ophthalmology, 98(4), 529-533. https://doi.org/10.1136/bjophthalmol2013-304485

Pulido, J. S., Pulido, C. M., Bakri, S. J., McCannel, C. A., \& Cameron, J. D. (2007). The use of 31-gauge needles and syringes for intraocular injections. Eye (London, England), 21(6), 829-830.

https://doi.org/10.1038/sj.eye.6702514

Qureshi, N. A., Mansoor, H., Ahmad, S., Zafar, S., \& Asif, M. (2016). Reducing intraocular-pressure spike after intravitrealbevacizumab injection with ocular decompression using a sterile cotton swab soaked in proparacaine $0.5 \%$ : A quasiexperimental study. Taiwan journal of 
ophthalmology, 6(2), 75-78. https:/ /doi.org/10.1016/j.tjo.2015.12.003

Sachdeva, M. M., Moshiri, A., Leder, H. A., \& Scott, A. W. (2016). Endophthalmitis following intravitreal injection of antiVEGF agents: long-term outcomes and the identification of unusual microorganisms. Journal of ophthalmic inflammation and infection, 6(1), 2. https://doi.org/10.1186/s12348-0150069-5

Semeraro, F., Morescalchi, F., Duse, S., Gambicorti, E., Cancarini, A., \& Costagliola, C. (2015). Pharmacokinetic and Pharmacodynamic Properties of Anti-VEGF Drugs After Intravitreal Injection. Current drug metabolism, 16(7), 572-584. https://doi.org/10.2174/1389200216666 151001120831

Shah, Chirag P; Garg, Sunir J; Vander, James F; Brown, Gary C; Kaiser, Richard S; Haller, Julia A; and The Post-Injection Endophthalmitis (PIE) Study Team (2011). "Outcomes and risk factors associated with endophthalmitis after intravitreal injection of anti-vascular endothelial growth factor agents." Ophthalmology, 118 (10): 2028-2034.

Solborg Bjerrum, S., Kiilgaard, J. F., Mikkelsen, K. L., \& la Cour, M. (2013). Outsourced cataract surgery and postoperative endophthalmitis. Acta ophthalmologica, 91(8),

701-708. https://doi.org/10.1111/aos.12279

Song, S., Yu, X. B., \& Dai, H. (2016). Effect of prophylactic intraocular pressurelowering medication (brinzolamide) on intraocular pressure after ranibizumab intravitreal injection: A case-control study. Indian journal of ophthalmology, 64(10), https://doi.org/10.4103/03014738.195006

Tufan, H.A., Vural, A.H., Gencer, B., Kara, S., Arıkan, S., \& Yuksel, E. (2013). Bacterial Contamination of Needles Used for Intravitreal Injections: Comparison between 27-gauge and 30-gauge Needles. Ocular Immunology and Inflammation, 21, 366 - 370, DOI: 10.3109/09273948.2013.801988

Uyar, E., Ulas, F., Sahin, S., \& Celebi, S. (2019). Major factors affecting intraocular pressure spike after intravitreal ranibizumab injection: Vitreous reflux and its amount. European Journal of Ophthalmology, 29(4), $361-$ 367. https://doi.org/10.1177/112067211 9836613 
المضاعفات التي تحثث للعين بعد حقن عقار الافاستين داخل العين: تقرير من مركز طبرق الطبي

فتحي عبدالكريم علي عبدالمجيد"**، جميلة صالح سعيد علي²

I قسم العبيون ، كلية الطب البشري جامعة طبرق ،طبرق ، لبييا

2 قسم الاطفال ، كلبة الطب البشري جامعة طبرق، طبرق ، لبييا.

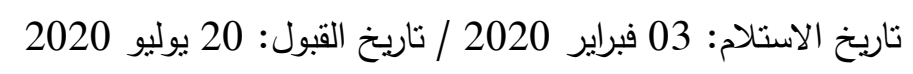
https://doi.org/10.54172/mjsc.v35i2.317:Doi

المستخلص: تم إجراء دراسة إحصائية بأثر رجعي على جميع المرضى الذين تلقوا الأدوية بالحقن داخل العين (أفاستين) في قسم المبر

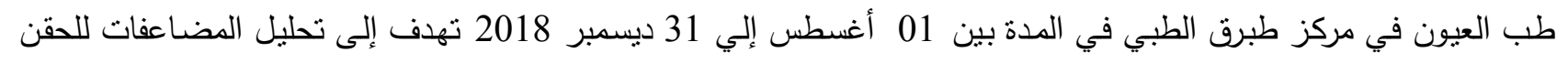

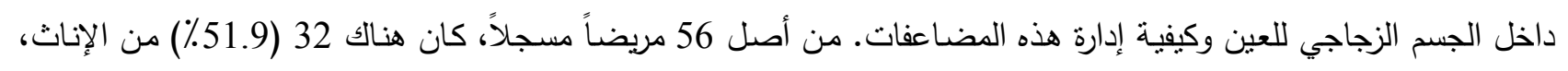

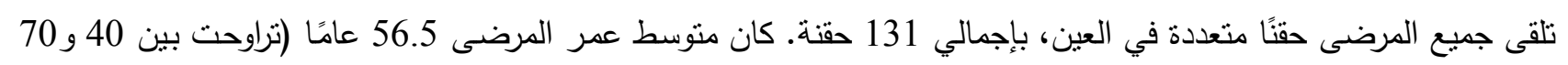

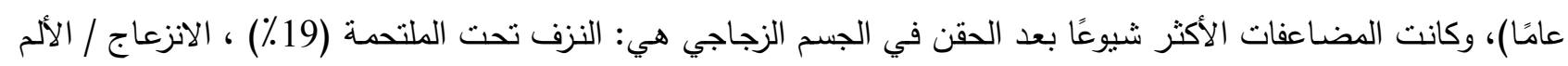

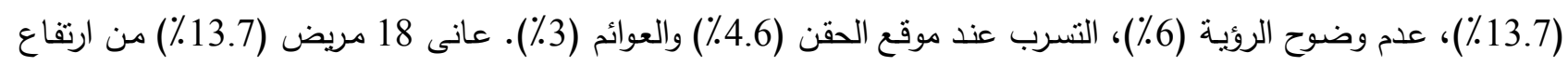

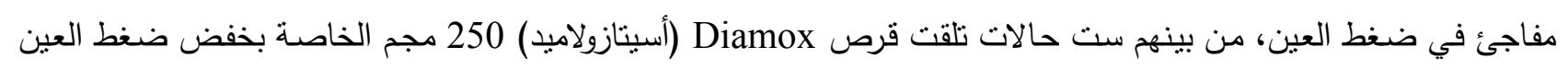

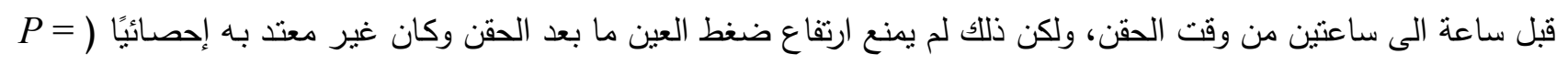

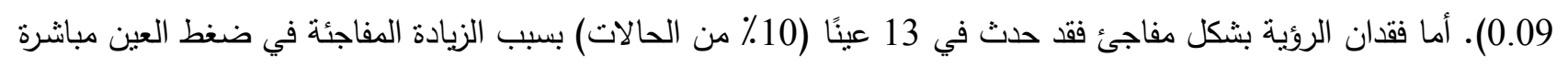

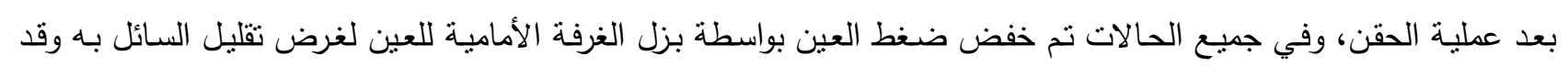

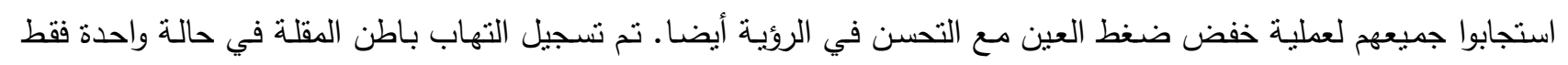

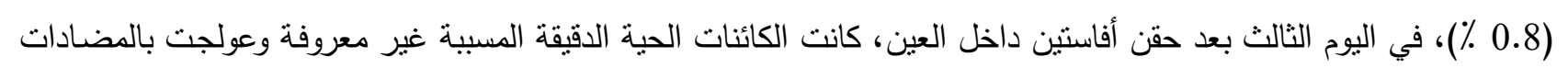

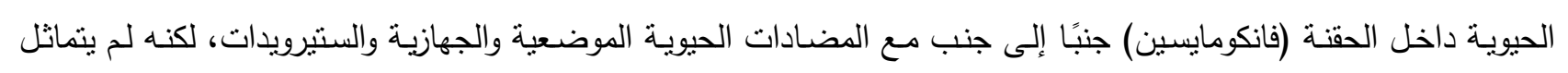

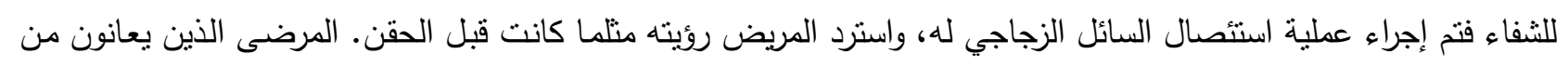

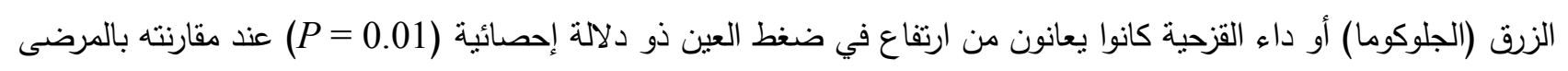

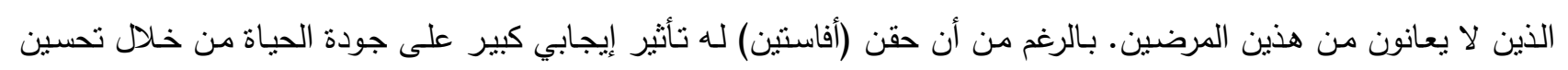

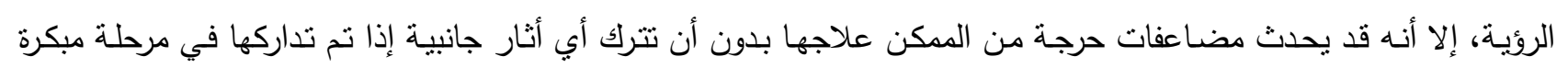
وبالطريقة العلاجية المناسبة. الكلمات المفتاحية : افاستين؛ المضاعفات؛ الحقن داخل الجسم الزجاجي؛ طبرق. 